Sipos, János. "Hooker, Lynn M. 2013. Redefining Hungarian Music from Liszt to Bartók. New York: Oxford University Press. 320 pp." Hungarian Cultural Studies. e-Journal of the American Hungarian Educators Association, Volume 9 (2016): http://ahea.pitt.edu DOI: 10.5195/ahea.2016.241

\title{
Hooker, Lynn M. 2013. Redefining Hungarian Music from Liszt to Bartók. New York: Oxford University Press. 320 pp.
}

\section{Reviewed by János Sipos, Institute of Musicology, MTA Research Centre for the Humanities}

As an ethnomusicologist I know the oeuvre of Ferenc/Franz Liszt (1811-1886) and Béla Bartók (1881-1945), albeit not as an expert of their works and lives. My field of interest is the remarkable nineteenth-century phenomenon of pioneering musicians like Bartók, Zoltán Kodály (1882-1967) and others who set out to learn, systematize, adapt and re-present Hungarian folk music as the music of the Hungarian nation. The project of these composers, as that of their coeval poets, prose-writers and other artists, has to be studied in the context of nineteenth century European nationalism, which entailed a new look at folk creation as the original form of the nation's higher art and therefore deserving to be played at concert halls no less than in villages and town-squares.

In her Redefining Hungarian Music from Liszt to Bartók, Lynn M. Hooker examines two parallel and intersecting projects carried out in the period under examination: one is the discovery of, or the new interest in, Hungarian folk music and the other is the beginning of creation of Hungarian classical music. Two composers whose work stems from the meeting or merging points of these two processes, Ferenc/Franz Liszt and Béla Bartók, stand at the center of Hooker's study. Liszt gained worldwide recognition as a child prodigy and virtuoso pianist, then started integrating gypsy music into his works and finally created works with a progressive French spirit that influenced all European music well into the mid-twentieth century. Bartók wished to create a whole new kind of music as well as base it on the solid ground of traditional Hungarian music, somewhat similarly to the projects of French composers such as Maurice Ravel (1875-1937) and Claude Debussy (1862-1918) in their musical and cultural setting.

In the closing sentence of the Introduction to her book, Hooker makes the connection between the works of the two Hungarian composers and the position of Hungary as a CentralEuropean country and culture: "Indeed the controversy over the definition of Hungarian music in the late nineteenth and early twentieth century is a microcosm of Hungary's deeply ambivalent vision of itself: whether it was to be the Eastern edge of Europe or the Western edge of Asia... Understanding this debate both provides a fuller sense of Liszt's relationship with Hungarian musical world and also expresses the richness of the revolution Bartók brought about in national as well as modern music" (17). In what follows I explicate Hooker's combined examination of nationalism and music in nineteenth-century Hungary by first surveying her book chapter by chapter and then discussing it as a whole.

Chapter One, "Rhapsody on Hungarian Themes," offers an exposition to the political and cultural history of Hungary from the Reform Era (1825-1848) to World War I. A central distinction that Hooker makes in this chapter is that between Gypsy-influenced magyaros, meaning Hungarian-style music, and traditional Magyar or Hungarian music. This chapter in fact addresses the question of what music can be defined and described as specifically Hungarian, while taking into consideration the geopolitical situation and cultural location of Hungary in

(cc) EY

ULIS D-Sonk 
Sipos, János. "Hooker, Lynn M. 2013. Redefining Hungarian Music from Liszt to Bartók. New York: Oxford University Press. 320 pp." Hungarian Cultural Studies. e-Journal of the American Hungarian Educators Association, Volume 9 (2016): http://ahea.pitt.edu DOI: 10.5195/ahea.2016.241

East-Central Europe and within the Austro-Hungarian Monarchy. To broaden her viewpoint Hooker discusses not only music but also other arts, especially painting, thereby asking whether there is such a thing as national music or national painting. And if such national forms of arts do exist then what makes them or how do they become internationally recognizable as the high culture of their nation?

Chapter Two, "The Liszt Centennial and Liszt's Legacy in Hungarian Musical Life," discusses Hungarian music, Liszt's national and international identity, and his role in Hungarian musical life. This chapter also discusses the Liszt Centennial events held in Budapest and in the Hungarian countryside, both within their European context, as well as the composer's virtuosity and adaptation or interpretation of Gypsy music. Chapter Three, "From Gypsies to Peasants: Race, Nation and Modernity," deals with the reception of Liszt and -- once again -- with the Liszt Centennial, this time presenting yet unstudied publications and other relevant literature. Hooker then expounds on the period of formation of the new Hungarian music created by Bartók and his followers, who wished to renew Hungarian classical music, yet felt it should be based on neither gypsy music nor German models and structures.

Chapter Four, "Writing Hungarian Music: Motive, Genre, Spirit," explores the rules formulated by theorists regarding Hungarian style and the debate they started. The author also analyzes the existence of some of these rules in certain works of Bartók and Kodály stressing that these composers strongly ridiculed those rules while implementing them. Thus Hooker paints a vibrant picture of the environment that enabled or necessitated the birth of the new Hungarian music, its repertoires and the time's writings about national style and genres. Citing examples of musical works of the period Hooker analyzes what can be termed Hungarian rhythm as well as its treatment in the works of Mihály Mosonyi (1815-1870), Ferenc Erkel (1810-1893), Ödön Mihalkovich (1842-1929) and Liszt, as well as explains Bartók's and Kodály's views on Hungarian rhythm. In this chapter Hooker draws our attention to the fact that the modern and hyper-modern styles had their roots in the traditional, age-old folk music. Bartók and his circle wished to turn away from the musical idioms based on newer urban magyar nóta and verbunkos and used old Hungarian folksongs instead.

In Chapter Five, "Cosmopolitan Nationalist Modernism," Hooker traces how modernist Hungarian composers succeeded in positioning themselves on the same European platforms and stages as did stars like Debussy and Italian composer Ferruccio Busoni (1866-1924); on which Hooker remarks that “... writings and scores illustrate how musicians in Bartók's circle... also highlighted the parallel between the Hungarian musicians' use of folk music and the historicist modernism of composers in the German and French scenes" (17). She then briefly introduces the aspirations of Hungarian composers who were at that time looking for an internationally accorded new sound and their inter-personal relationships. Here Hooker points out that despite the centuries-old Hungarian-Austrian-German knot in Hungarian musical history, the HungarianFrench tie proved to be even stronger. Finally, in the book's "Epilogue" the author surveys the changes in the Hungarian-music scene since the time when Liszt first published his Des bohemians to Bartók's era.

On the whole Hooker convincingly demonstrates in her study the arguments of international and Hungarian experts regarding the Hungarian-ness of Liszt and Bartók. Her strength lies in her walking the golden path between those stamping patriots as nationalists and those who think of their own culture as the only true and valuable one. I wish to add here a few thoughts about the Hungarian-ness of the two geniuses at the center of this book. Liszt was born Hungarian and although he could hardly speak the language and became famous as a charismatic 
Sipos, János. "Hooker, Lynn M. 2013. Redefining Hungarian Music from Liszt to Bartók. New York: Oxford University Press. 320 pp." Hungarian Cultural Studies. e-Journal of the American Hungarian Educators Association, Volume 9 (2016): http://ahea.pitt.edu DOI: 10.5195/ahea.2016.241

performer outside Hungary, he always declared himself Hungarian, especially after the 1838 great flood of Pest. This is not difficult to understand: in Hungary he was not only a celebrated musician but also a respected and beloved compatriot, the pride of the Hungarians, the founder of the Academy of Music and a few more titles. At the beginning of his career he was influenced by the popular Gypsy style that stressed show and so-called glittering ornamentation. But as Hooker points out, by his late works with their chromaticism and tonal ambiguity, Liszt belongs to the mid-twentieth century modern currents, being a predecessor of Debussy, Ravel and the new Hungarian School.

In the case of Bartók the composer's Hungarian identity was never in question. Moreover, in accordance with the spirit of his time he had an explicit "Hungarian period" of creation. Yet, he never turned towards a pejorative form of nationalism but always expressed his patriotism in the best or most balanced sense. Bartók started his career in Hungary and became internationally renowned only after his death, at which time composers gained inspiration from his unusual Asian-rooted pentatonic folk songs that had sounded strange or foreign to his coeval listeners.

The above short summary of the lives and careers of the two composers shows that both were prominent musicians who saw and declared themselves as Hungarian, yet their genius was internationally acknowledged as stemming from or fertilized by their local-national environment. Such a duality is, in fact, not exceptional for outstanding artists: at the highest levels the national and the cosmopolitan components often merge and mutually influence each other. Artists often "import" external trends and integrate them in their work, but in the case of the two composers at hand the opposite tendency, of "exporting" Hungarian folk music, is the more outstanding phenomenon.

Relating to Theodore Adorno's claim that the modern and international inevitably depart from the traditional and national, Hooker poses the question whether Bartók can be considered modern as well as "national." In my opinion in Bartók's case this is not a dichotomy, especially if we remember his proposal to first to learn folk music as a kind of mother tongue and then forget its concrete forms, thus holding in mind and applying only its essence. Another phenomenon that pushed Bartók and his companions to create new music was the pentatonic character of old Hungarian folksongs, which needed a unique harmonization.

Finally, since the author devotes much space to ethnic issues, I would have been happy to read a little more about Liszt's and Bartók's writings as well as comments on these and close issues. At the same time it is good that the book is not dominated by ethnicity issues beyond addressing them as needed. I would have also applied a bit more of an international perspective in order to place the Hungarian case of nationalism and re-creation of folk art, and that of borrowing values as opposed to hailing the nation's own, in broader contexts. To sum, Lynn Hooker created a well-constructed and well-written study of the circumstances of creating art in general and music specifically and about the relationship of national and supranational art in nineteenth-century Hungary, all in light of the work of two giant Hungarian musicians.

Lynn Hooker's Redefining Hungarian Music from Liszt to Bartók thus makes a significant addition to previous studies on her subject-matter (such as the works of Alan Walker, Dezsö Legány, Judit Frigyesi and David Schenider). This study is addressed not only to musicians and musicologists but also to others wishing to learn more about the development of Hungarian music in the turn of the nineteenth and twentieth century, its ties to social and cultural processes of that era and the ways in which various kinds of Hungarian music were accepted by different audiences. 